\title{
Review Article: William James and the Varieties of Contemporary Religion
}

\section{ROGER O'TOOLE}

The Varieties of Religious Experience: A Study in Human Nature

(Centenary Edition) with a foreword by Micky James and new introductions by Eugene Taylor and Jeremy Carrette

WILLIAM JAMES, 2002

London \& New York: Routledge,

lxiii + 415 pp., £12.99, US\$18.95, Can \$28.95 (hb)

ISBN 0-415-27809-0

\section{Varieties of Religion Today: William James Revisited}

CHARLES TAYLOR, 2002

Cambridge, MA \& London: Harvard University Press

vii + 127 pp., US\$19.95, £13.95 (hb), US\$12.00, £7.95 (pb)

ISBN 0-674-00760-3 (hb), ISBN 0-674-01253-4 (pb)

When the distinguished American writer John Updike published a short story based on the events of 11th September 2001, he entitled it "Varieties of Religious Experience" (Updike, 2002), undoubtedly confident of the immediate and specific response this phrase would evoke in an educated readership. William James's The Varieties of Religious Experience is a genuine classic, not merely within the diverse strands of religious scholarship, but in that wider philosophical and literary world of great books which are required reading for anyone of cultural and intellectual sophistication. Indisputably one of the most widely read books on religion in the English language, Varieties (the most renowned result of James's 35 years of research related to religion) was continually reprinted in many languages during the twentieth century, frequently accompanied by laudatory re-introductions by currently influential luminaries. ${ }^{1}$

The first English edition of the new century is, appropriately, a centenary production prefaced by a brief familial benediction from the author's grandson and two lengthy, sympathetic, and trenchant scholarly introductions. While not intended as a definitive academic publication in the manner of the Harvard edition (James, 1985) ${ }^{2}$ this new commemorative edition offers an accessible, well-produced, and reasonably priced clothbound re-set printing of the revised 1902 text (together with a new index), which unambiguously asserts the significance of its contents for contemporary scholarship.

Those few hundred souls to whom James delivered (in 1901 and 1902) the prestigious Gifford Lectures on Natural Religion in Edinburgh, which provided the text for his book, can hardly have anticipated the millions who would 
subsequently ponder James's words. Nor could they have imagined the celebratory scrutiny that the content and form of his message would still stimulate a century later. Unsurprisingly, the salience of a commemorative edition of Varieties is heavily underlined by a number of recently or imminently available cognate publications. ${ }^{3}$ Among these, the elegant contribution of the distinguished Canadian philosopher Charles Taylor, himself a former Gifford Lecturer, is especially noteworthy. ${ }^{4}$

Like many other classics, James's book has, from the time of its first appearance, been accorded a reception varying from extreme approbation to intense repudiation. As a multi-valent text, which can be read as psychology, philosophy, science, and literature, it has been celebrated as a work of genius which lays the foundations of a genuine 'science of religion' and derided as a seductive, credulous, and misleading conduit of faith and irrationality. ${ }^{5}$ Acutely aware of the historical hostility, long-standing suspicion, and contemporary indifference to James's ideas, especially among academic psychologists, the authors of the introductions to the Varieties centenary edition are, nonetheless, forthright in asserting their persisting and inescapable relevance for research in the psychology of religion.

In exploring the 'spiritual roots' of his psychological insight into religion, Eugene Taylor sketches the crucial events in James's intellectual and emotional biography, indicating his long struggle to philosophically balance and blend the religious and scientific aspects of his nature. Outlining the Swedenborgian and Transcendentalist origins of James's "naturalistic theism which posited the existence of God, but coming to us through the interior life of the individual", Taylor ponders the relevance-for the contemporary fields of medicine, psychology, philosophy, and religion-of James's certainty that "the mother sea and fountain-head of all religions lies in the mystical experiences of the individual" (p. xxxiv). ${ }^{6}$

Noting that most American and European philosophers "remain dominated by the analytical tradition and their work no longer contains any iconography of the transcendent" (p. xxxvi), Taylor observes with consternation that, with few exceptions, "mainstream academic scientific psychology has stayed remarkably insulated from the subject of mysticism" (p. xxxvii) and depicts a disciplinary drift towards cognitive neuroscience as "reductionistic and exclusionary" (p. xxxviii). Although, in such circumstances, James's final call to his colleagues "to study the fall of the threshold of consciousness ... to the point where it touches the transcendent in mystical awakening" (p. xxxvi) would seem unlikely to entice a positive contemporary response from within the community of academic psychologists, Taylor is remarkably sanguine regarding "a revival of the field called the psychology of religion within psychology as James originally conceived it in Varieties" (p. xxxviii). Indeed, he explicitly predicts that "the humanistic implications of the neuroscience revolution are already pervasive enough that the revolution itself has now passed out of the hands of the reductionists who started it, making its eventual outcome completely unknown" (p. xxxviii). In almost prophetic mode, Taylor foresees the emergence of "a new generation of psychologists", grounded in the biology of consciousness, who are more philosophically critical of the conduct and claims of science. Such scholars will be "more phenomenological in understanding the person, more existential 
about their absolute assurance of method, more cognizant of the reality of transcendent experiences, more cross-cultural and comparative, and more visionary in the way they conceive the agenda of their discipline" (p. xxxviii).

Less explicitly optimistic than Taylor in contemplating a "return to James" in the psychology of religion, Jeremy Carrette, nonetheless, forcefully recounts the potential benefits of such a strategy for a discipline currently enraptured in the realm of neuroscience. Drawing on the insights of Michel Foucault, he suggests that James's prestige as a founding father of psychology camouflages a regrettable "disciplinary amnesia" which characterises and subverts the "contemporary engagement between psychological theory and religion" (p. xl). Noting that James begins Varieties with a discussion of neurology and a critique of reductionistic 'medical materialism', Carrette condemns many contemporary psychological accounts of religious experience for perpetuating philosophical errors (which James incisively exposed a century ago) while simultaneously promulgating the notion that scientific progress has somehow resolved "all epistemological and hermeneutical problems" (p. xliii). In a plea remarkably similar to those of sociologists expounding the centrality of the classics or urging a return to the disciplinary heritage of the founding fathers, ${ }^{7}$ Carrette recommends remembrance, reading, and re-reading of James as a means of restoring self-understanding to the psychology of religion through an examination of its "foundational practices" and an appreciation of the "provisionality and uncertainty" of its knowledge (p. xli-xliv).

Contrasting the ambitions and presumptions of contemporary psychological investigations with the foundational "methodological humility" of James's examination of religious experience, Carrette detects a "fundamental methodological flaw in much of the recent work applying neuroscience to religion" (p. 1). In his view, such reductionist accounts involve a "fundamental category error" which obscures the distinction between the existential and the spiritual, misrepresents the linkage between neurological functions and religious experience, and underrates the complexity of religion as a linguistic-cultural phenomenon (p. li-liii). In its failure to recognise that "the location of an 'experience' in neural processes" cannot determine or explain religious reality, reductionist scientific psychology arrogantly ventures to supply insight and analysis far beyond the physical and mechanical scope and "limits of its own disciplinary apparatus". Reality, Carrette asserts, is "far more complex than materialist science can appreciate" and thus, while neuroscience tells us a lot about the brain, "it tells us very little about religion" (p. liv-lviii).

The antidote to this fundamentally flawed version of empiricism involves, in Carrette's estimation, a profound shift from the experimental to the experiential through a return to the "imprecision and insight" of the Jamesian perspective (p. lix). Emphasising that "human experience, with all its problems of representation, constantly escapes the analysis of the natural sciences" (p. lix), Carrette pointedly observes that brain scans are of limited utility in the absence of individuals' own reports or narratives of their experience. James's methodological accentuation of the discursive context or framing of immediate experience is, therefore, entirely praiseworthy, even to the extent that "the psychological study of religion has not progressed beyond James's own basic 
insights on the nature and assessment" of such experience (p. lxii). Varieties, in Carrette's opinion, continues to have "much to teach contemporary psychology of religion and neuroscience in the twenty-first century" (p. lxiii).

Charles Taylor's short, but intellectually packed revisiting of Varieties presents an abundance of perceptive philosophical (and sociological) insight into the thought of a "long-dead author [who] is in striking ways a contemporary" (p. vii). Expressing astonishment at "how little dated" this "immensely rich and multifaceted book" is, he emphasises his "powerful recurring impression" that much of it "could have been written yesterday". Moreover, Taylor observes, such a response speaks volumes, not only regarding James's remarkable prescience, but about ourselves and "where we have come in our own society and culture a century later" (p. v). Enthralled by the almost eerie way in which Varieties succeeds in capturing "something essential of our present predicament", Taylor adopts "a very specific agenda, asking what it can tell us about the place of religion today" (p. vi). More precisely, however, his book is an attempt to articulate his own view of the place of religion in our secular age, in the form of a conversation/confrontation with James (p. vi).

As this encounter implies, Taylor is by no means uncritical of many of James's fundamental ideas. Thus, speculating on the extent to which various aspects of James's background conspire to give him a "mangled and partial view of some of the important phenomena of modern religious life", he notes explicitly that "James got certain things wrong; or saw some important phenomena less undistortively than others" (p. 21-22; see p. 20-29 \& p.111-116 for Taylor's incisive criticisms). Despite significant reservations concerning some aspects of his work, Taylor unabashedly acknowledges "the wide sympathy, coupled with unparalleled phenomenological insight, which mark James as the exceptional figure that he is". This, he believes, is "why we go on reading this book, and will go on finding ideas of extraordinary value in it well after its centenary has passed" (p. 22).

James got many things right, of course, to a degree that Taylor is concerned that "the close fit between James's take on religion and certain aspects of modern culture" may seduce some scholars into believing that "what James describes as religious experience is the only form that religion can assume today", when this is decidedly not the case (p. 22). Despite his belief that James's analysis of religious experience is overly individualistic, sociologically deficient, unduly dismissive of theology, and unduly Protestant in attitude, Taylor is convinced that his concentration on individual experience and feelings as the primary source of religion is indispensable to an understanding of religion in the present day. In this estimation, James's view of religion is "very much at home in modern culture", for its concern with personal commitment and devotion "rather than collective ritual" (p.9) endorses a central theme of western modernity long interwoven with an impetus towards secularity.

In arguing that "James's stress on personal religion, even his insistence that this is what religion really is, as against collective practice, can seem entirely understandable, even axiomatic to lots of people" in the North Atlantic regions today (p. 13), Taylor suggests that this is linked to his accurate rendering of the main forms of spiritual malaise in his time. As these forms of anguish "continue to haunt the world today" (p. 37), James can be credited with "an extraordinary insight into the spiritual needs of the modern world" (p. 41). 
As a philosopher who "believes that philosophy must be supplemented by faith" (Ryan, 1995: 361), Taylor is naturally sympathetic to James's apologia pro fide sua: his pronouncement regarding the limits of science and the scope of faith and intuition in the human pursuit of knowledge. Unlike the many scholars who have condemned James as a religious apologist or scientific apostate on the basis of his argument concerning the admissability and intellectual respectability of belief or faith in a secular age, he appreciates the philosophical merit in James's position. ${ }^{8}$ More important than this, he also comprehends the significance of James's stance for the understanding of the nature of religion in a world dominated by science. Thus, whether one agrees with James or not, his critique of rationalism as presenting only a partial and superficial account of mental life has, in Taylor's judgement, "opened up to view an important part of the struggle between belief and unbelief in modern culture" (p. 52).

Although it undoubtedly underscores his acute sympathetic sensitivity to spiritual needs, James's privileging of personal religious experience would surely seem understandable and acceptable to many members of post-industrial societies, in Taylor's view, simply because it reflects the reality of contemporary religious life. In depicting this reality, Taylor only employs a fraction of the available sociological material, yet his succinct account (in Chapter 3), which uses classic theory and current research, is a masterly sociological exploration of the individualisation and privatisation of religiosity which accompanies a decline in public religion.

Asserting that the conspicuously secular character of contemporary society has made religious faith increasingly a matter of conscious personal choice, Taylor traces the growing disjunction between belief and belonging, in a broad sense, to the inherent instrumentally individualistic momentum of modernity and, in a more precise way, to the mass dissemination of a romantic notion of expressive individualism through which each of us uniquely realises his/her own humanity. Having articulated "neo-Durkheimian" and "paleo-Durkheimian" models of the interdependence among church, state, society, and the individual, Taylor hypothesises a destabilisation, dislocation or dismantling of these dispensations and the dawn of a post-Durkheimian age in which people are gradually released or explosively expelled to face the terrors of a "fractured world" alone (p. 106). This new dispensation "changes utterly the ways in which ideals of order used to be interwoven with the polemic between belief and unbelief" (p. 96).

"Something has happened in the last half century", observes Taylor, "which has profoundly altered the conditions of belief in our societies" as well as situating us "at a rather new phase of religious life and one which James in a sense prefigured" (p.79-80). Expressivist culture, with its emphasis on self-fulfilment, privacy, authenticity, relativism, and rights, together with its displacement of common action by mutual display, has created a new form of "social imaginary", "a new way of being together in society", and consequently "a quite new predicament" for contemporary human beings (p. 88, 107). In such circumstances, suggests Taylor, intensity of passion and spiritual insight or feeling have become the paramount virtues that they are in James's "stripped-down" religious landscape (p. 63, 99-100). Conscious, indeed insistent, that his own portrayal of contemporary religion offers no "global vindication of James's idea of religious experience" (p. 64), Taylor illustrates, however, that, in 
many respects, our world "is a paradigmatically Jamesian one", in which individuals interpret and act upon their religious experiences and emotions independently of formal religious organisations or society in general (p.111). After reiterating that James "saw deeply into an essential feature of our divided age" and recognised that religious experience is "crucial as never before ... in our divergent spiritual lives", Taylor concludes that it is "because he saw this with such intensity, and could articulate it with such force that [his] book lives on so strongly in our world" (p. 116).

With the utmost lucidity, Varieties reveals, in its strengths, weaknesses, and ambiguities, the social, intellectual, and emotional experience as well as the brilliant, forceful, sympathetic, tormented, and divided personality of its author. James's almost prophetic insight into the character of religion at the turn of the twenty-first century is rooted in a personal biography and academic career which afforded an unimpeded view of the culmination and mutual encounter, at the turn of the twentieth century, of certain significant Victorian perspectives on science, philosophy, psychology, and religion. Through his comprehension of the parallel outlooks of experimental science and fashionable spirituality of his own time, James described the dynamics of human nature in a world which, as an embryonic version of our own, prompted those insights which have led scholars, a century later, to converse with him almost as a contemporary. Whether, in his Pascalian bid to strike the right balance between science and mysticism, James deserves credit for resisting the conventional agnosticism of prevailing scientific opinion or merits disapproval for succumbing to the sentiments of what the German theologian Ernst Troeltsch (1931: Vol. 2, 791-795) called "the secret religion of the educated classes", his empathic unravelling and judicious evaluation of the claims of reason and faith retain the power to stimulate the intellects, emotions, and intuitions of contemporary readers. ${ }^{9}$ Above all, they challenge them to make up their own minds in the battle between belief and unbelief, which still rages in modern culture.

During the last two decades, Varieties has not only retained its relevance, but has, arguably, intensified its potential significance for humanistic psychology, sociology, and religious studies, as scholars have imparted detailed documentation of the increasingly diffuse, autonomous, privatised, 'do-it-yourself', 'self-help', and experimental character of religion in post-modern societies. In a world where 'belief without belonging' (see Davie, 1990) has become progressively familiar and in which religion is, more and more, perceived as a resource (to be drawn upon syncretically according to individual need or desire) rather than as a collectively grounded, authoritative source of meaning (see Beckford, 1992: 170-172), James's viewpoint appears extraordinarily appropriate and timely. ${ }^{10}$ In like manner, a discernible tipping of the cultural balance between intellect and emotion to a point where, in a broadening sphere, feeling outweighs thinking would seem to endorse James as a congenial guide to the current human condition.

A reductionistic scientific psychology, as James himself makes clear in Varieties, can never yield a credible rendition of religion any more than the propositions of contemporary neuroscience can be recognised as total explanations of religious phenomena by humanistically, phenomenologically or sociologically inclined scholars. This book has attained the status of a classic because, as much a work of art as a scientific treatise, it contributes a brilliant 
discourse to a number of academic disciplines and to the reading public through the use of "modes of argument which are more consistently generalized and speculative than are normal scientific discussions" (Alexander, 1987: 22-27). Jeffrey Alexander draws upon Foucault and Habermas in his use of the term 'discourse', and in his terms, Varieties may be viewed as a multi-valent text which "seeks persuasion through argument rather than prediction" and whose persuasiveness "is based on such qualities as logical coherence, expansiveness of scope, interpretive insight, value relevance, rhetorical force, beauty, and texture of argument" (ibid: 28-29).

In recent years, sociologists have pondered the tenacious prominence of a classical canon of writings within their discipline, despite the impatient hostility of many practitioners dedicated to a cumulative and systematic version of the social-scientific enterprise. Their catalogue of reasons why certain works attain and retain highly privileged status and their inventory of intrinsic and extrinsic functions of classics within disciplinary and sub-disciplinary discourses undoubtedly represent invaluable resources for any sustained, comprehensive assessment of the impact of Varieties upon generations of readers. Although such appraisal cannot be undertaken here, brief concluding mention may be made of the striking significance of the variously itemised intrinsic intellectual merits of sociological classics.

Commentary on the great works of the sociological founding fathers is frequently far removed from austere annotation of the accuracy of precise propositions. Collectively composing a rich heritage, these texts are individually depicted as touchstones or models which not only "keep the diverse perspectives and insights of the past alive as options for the present", but constitute by definition "the best stuff the discipline ... has produced in the course of its history" (Levine, 1985: 15; Stinchcombe, 1982: 5; Poggi, 1996: 39; Merton, 1968: 36). As "concrete manifestations of aesthetic principles", these scholarly works are described as furnishing the minds of contemporary readers with intellectual standards of taste and judgement rather than merely supplying sets of hypotheses for verification. Thus, despite the undisputed fact that the sociological classics "are so often wrong", their greatness remains unimpaired and their periodic re-reading is widely recommended as a perpetual source of disciplinary revitalisation (Levine, 1985: 5; Mills, 1960: 3; Merton, 1968: 36-37; Parsons, 1981: 183-194).

Those rare "qualities of personal sensibility-aesthetic, interpretative, philosophical, observational" by which sociological classics transcend mere problem-solving and make their "singular and continuing contribution" are clearly much in evidence in the writings of William James. Imbued with its author's characteristically "idiosyncratic abilities to experience, to understand and to know" (Alexander, 1987: 28), it appears singularly unsurprising that Varieties, whether one agrees with its contentions or not, has, in Charles Taylor's words, "resonated for a hundred years and will go on doing so for many years to come" (p. 60). ${ }^{11}$

Roger O'Toole is Professor of Sociology, cross-appointed to the Centre for the Study of Religion, at the University of Toronto, Canada. CORRESPONDENCE: Department of Social Sciences, University of Toronto, Scarborough Campus, 1265 Military Trail, Scarborough, Ontario MIC 1A4, Canada. 


\section{NOTES}

1. See, for example, the introductions to the New American Library (1958), Collier (1961), and Penguin (1985) popular editions by Jacques Barzun, Reinhold Niebuhr, and Martin Marty respectively. A listing of some major editions in various languages is provided in Eugene Taylor's introduction to the Centenary Edition (p. xv, note 1). See also the list of English-language editions, audio recordings, and translations provided by David M. Wulff's Annotated Bibliography in Donald Capps and Janet L. Jacobs (1955: 281-283). The scope and significance of James's subtitle are worthy of note.

2. As a volume in the Collected Works of William James, this edition includes 216 pages of supplementary sources, appendices, and editorial detail.

3. See, for example, the special issue of Journal of Speculative Philosophy (Anderson, 2003), which focuses on the Varieties centenary; Cardeña, Lynn \& Krippner's Varieties of Anomalous Experience (2000); and a forthcoming publication (edited by Jeremy Carrette) based on the 2002 Edinburgh conference devoted to international and interdisciplinary exploration of "William James and the Psychology of Religion".

4. Taylor's book is based on a series of lectures given on the centenary of Hans Gadamer's birth under the auspices of the Vienna Institute for Human Sciences.

5. See the range of opinion encountered in Capps and Jacobs (1995), including entries in the Annotated Bibliography. For a recent review of the most common criticisms of Varieties, see Carol Zaleski, 1993-94.

6. As Taylor indicates, this 'oft quoted phrase' appears in a letter to Rev. Henry William Rankin (see James, 1920: 149-150).

7. For an overview of this sociological literature, see O'Toole (2001).

8. James's contemporary, the great French sociologist Durkheim, rather sarcastically described him as an "apologist of the faith" (Durkheim, 1961: 464). Taylor appreciates the degree of ambiguity in James's stance, distinguishing between stronger and weaker readings of his argument (see p. 42-48).

9. James's (and Troeltsch's) insight into the individualistic character of modern religiosity is anticipated to a degree by Tocqueville's appreciation of the pantheistic, spiritualistic, and mystical potential of American religion (Tocqueville, 1945: 32-35, 142-143). It is interesting to compare and contrast James's views with Weber's observations on the tension between science and faith (see Weber, 1946).

10. However, individualised versions of religiosity have by no means supplanted collective forms (see Casanova, 1994).

11. James's resonance casts further doubt on the relevance, for the human sciences, of Whitehead's observation that "a science which hesitates to forget its founders is lost" (see Whitehead, 1917: 115).

\section{REFERENCES}

Alexander, J. C. "The Centrality of the Classics." In Giddens, A. \& Turner, J., eds. Social Theory Today. Stanford, CA: Stanford U. P., 1987: 11-57.

Anderson, D., ed. Journal of Speculative Philosophy 17(1), 2003 (new series).

Beckford, J. A. Religion and Advanced Industrial Society. London \& New York: Routledge, 1992.

Capps, D. \& Jacobs, J. L., eds. The Struggle for Life: A Companion to William James's The Varieties of Religious Experience. Society for the Scientific Study of Religion Monograph 9, 1995.

Cardeña, E.; Lynn, S. J. \& Krippner, S. Varieties of Anomalous Experience: Examining the Scientific Evidence. Washington, DC: American Psychological Association, 2000.

Casanova, J. Public Religions in the Modern World. Chicago: University of Chicago Press, 1994.

Davie, G. "Believing without Belonging: Is this the Future of Religion in Britain?" Social Compass 37, 1990: 456-469.

Durkheim, E. The Elementary Forms of the Religious Life. J. W. Swain, trans. New York: Collier, 1961 (first published in French in 1912).

James, H., ed. Letters of William James. Vol. 2. Boston: Atlantic Monthly Press, 1920.

James, W. The Varieties of Religious Experience (with an introduction by John E. Smith). Cambridge, MA: Harvard U. P., 1985.

Levine, D. N. "On the Heritage of Sociology." In Suttles, G. D. \& Zald, M. N., eds. The Challenge of Social Control. Norwood, NJ: Ablex, 1985: 13-19. 
Merton, R. K. “On the History and Systematics of Sociological Theory." In Merton, R. K. Social Theory and Social Structure. New York: Free Press, 1968: 1-38.

Mills, C. W. "Introduction-the Classic Tradition." In Mills, C. W., ed. Images of Man. New York: George Braziller, 1960: 1-11.

O'Toole, R. "Classics in the Sociology of Religion: An Ambiguous Legacy." In Fenn, R. K., ed. The Blackwell Companion to Sociology of Religion. Oxford: Blackwell, 2001: 132-160.

Parsons, T. "Revisiting the Classics throughout a Long Career." In Rhea, B., ed. The Future of the Sociological Classics. London: George Allen and Unwin, 1981: 183-194.

Poggi, G. "Lego Quia Inutile: An Alternative Justification for the Classics.” In Turner, S. P., ed. Social Theory and Sociology: The Classics and Beyond. Oxford \& Cambridge, MA: Blackwell, 1996: 39-47.

Ryan, A. John Dewey and the High Tide of American Liberalism. New York \& London: Norton, 1995.

Stinchcombe, A. L. "Should Sociologists Forget their Mothers and Fathers?" The American Sociologist 17, 1982: 2-11.

Tocqueville, A. de. Democracy in America. Vol. II. H. Reeve, trans. New York: Alfred K. Knopf, 1945 (first published in French in 1840).

Troeltsch, E. The Social Teaching of the Christian Churches. 2 Vols. O. Wyon, trans. London: George Allen and Unwin, 1931 (first published in German in 1911).

Updike, J. "Varieties of Religious Experience: A Short Story." The Atlantic Monthly 290 (4, November), 2002: 93-104.

Weber, M. "Science as a Vocation." In Gerth, H. H. \& Mills, C. W., trans. \& eds. From Max Weber: Essays in Sociology. New York: Oxford U. P., 1946: 129-156 (lecture first delivered in German in 1918).

Whitehead, A. N. The Organization of Thought: Educational and Scientific. London: Williams \& Norgate, 1917.

Zaleski, C. "Speaking of William James to the Cultured among his Despisers." Journal of the Psychology of Religion 2-3, 1993-94: 127-170. 
